\title{
Vitamin D deficiency is associated with an increased autoimmune response in healthy individuals and in patients with systemic lupus erythematosus
}

\author{
Lauren L Ritterhouse ${ }^{1,2}$, Sherry R Crowe ${ }^{1}$, Timothy B Niewold ${ }^{3}$, Diane L Kamen ${ }^{4}$, Susan R \\ Macwana $^{1}$, Virginia C Roberts ${ }^{1}$, Amy B Dedeke ${ }^{1,2}$, John B Harley ${ }^{1,5}$, R Hal Scofield ${ }^{1,2}$, Joel \\ M Guthridge ${ }^{1}$, and Judith A James ${ }^{1,2}$ \\ ${ }^{1}$ Arthritis and Clinical Immunology, Oklahoma Medical Research Foundation, Oklahoma City, \\ Oklahoma, USA \\ ${ }^{2}$ Departments of Medicine and Pathology, University of Oklahoma Health Sciences Center, \\ Oklahoma City, Oklahoma, USA \\ ${ }^{3}$ Gwen Knapp Center for Lupus and Immunology Research, University of Chicago, Chicago, \\ Illinois, USA \\ ${ }^{4}$ Division of Rheumatology and Immunology, Medical University of South Carolina, Charleston, \\ South Carolina, USA \\ ${ }^{5}$ Division of Rheumatology, Cincinnati Children's Hospital Medical Center and US Department of \\ Veterans Affairs Medical Center, Cincinnati, Ohio, USA
}

\begin{abstract}
Objectives-Vitamin D deficiency is widespread and has been associated with many chronic diseases, including autoimmune disorders. A study was undertaken to explore the impact of low vitamin D levels on autoantibody production in healthy individuals, as well as B cell hyperactivity and interferon $\alpha$ (IFN $\alpha$ ) activity in patients with systemic lupus erythematosus (SLE).

Methods-Serum samples from 32 European American female patients with SLE and 32 matched controls were tested for 25-hydroxyvitamin D (25(OH)D) levels, lupus-associated autoantibodies and serum IFN $\alpha$ activity. Isolated peripheral blood mononuclear cells were tested for intracellular phospho-ERK $1 / 2$ as a measure of B cell activation status.
\end{abstract}

Results-Vitamin D deficiency $(25(\mathrm{OH}) \mathrm{D}<20 \mathrm{ng} / \mathrm{ml})$ was significantly more frequent among patients with SLE ( $\mathrm{n}=32,69 \%)$ and antinuclear antibody (ANA)-positive controls $(\mathrm{n}=14,71 \%)$ compared with ANA-negative controls $(\mathrm{n}=18,22 \%)$ (OR 7.7, 95\% CI 2.0 to 29.4, $\mathrm{p}=0.003$ and OR $8.8,95 \%$ CI 1.8 to $43.6, \mathrm{p}=0.011$, respectively). Patients with high B cell activation had lower mean (SD) 25(OH)D levels than patients with low B cell activation (17.2 (5.1) vs 24.2 (3.9) ng/

\footnotetext{
Correspondence to: Judith A James, Arthritis and Clinical Immunology, Oklahoma, Medical Research Foundation, 825 NE 13th Street, Oklahoma City, OK 73104, USA; judith-james@omrf.org.

Additional data (Supplementary material) are published online only. To view these files please visit the journal online at (http://ard.bmj.com).

Competing interests JBH has served as a consultant for BioRad and owns stock in IVAX Diagnostics. All other authors have no competing interest.

Ethics approval This study was conducted with the approval of the Oklahoma Medical Research Foundation (OMRF) and the University of Oklahoma Health Sciences Center.

Provenance and peer review Not commissioned; externally peer reviewed.
} 
$\mathrm{ml} ; \mathrm{p}=0.009)$. Patients with vitamin D deficiency also had higher mean (SD) serum IFN $\alpha$ activity than patients without vitamin D deficiency (3.5 (6.6) vs $0.3(0.3)$; $\mathrm{p}=0.02)$.

Conclusions-The observation that ANA-positive healthy controls are significantly more likely to be deficient in vitamin D than ANA-negative healthy controls, together with the finding that vitamin D deficiency is associated with certain immune abnormalities in SLE, suggests that vitamin $\mathrm{D}$ plays an important role in autoantibody production and SLE pathogenesis.

Vitamin D deficiency has been associated with several autoimmune diseases including multiple sclerosis (MS), rheumatoid arthritis (RA), type 1 diabetes mellitus, inflammatory bowel disease (IBD), mixed connective tissue disease, autoimmune thyroid disease, scleroderma and systemic lupus erythematosus (SLE). ${ }^{1-9}$ Vitamin D levels are lower in individuals with undifferentiated connective tissue disease than in controls, and lower in patients who progressed to well-established connective tissue diseases than in those whose did not progress. ${ }^{10}$

Vitamin D supplementation has been shown to improve disease in murine models of MS, RA, type 1 diabetes mellitus, IBD and SLE. ${ }^{11}$ Addition of vitamin D and its synthetic analogues to murine models of SLE have resulted in improved dermatological disease, reduced proteinuria and increased survival. ${ }^{1}$ SLE is a complex heterogeneous autoimmune disorder arising from genetic predisposition and environmental risks. ${ }^{1213}$ Vitamin D deficiency has been found in approximately two-thirds of patients with SLE, with approximately one-fifth of patients having severe deficiency $(<10 \mathrm{ng} / \mathrm{ml}) .^{2}$ Additionally, serum vitamin D levels have been shown to correlate inversely with disease activity. ${ }^{14-16}$

Vitamin D has modulatory effects on B lymphocytes and Ig production. Many immune cells contain vitamin $\mathrm{D}$ receptors-including monocytes, macrophages, dendritic cells and activated $\mathrm{T}$ and $\mathrm{B}$ cells - and these immune cells possess the enzymatic machinery ( $1 \alpha$ hydroxylase, CYP27B1) necessary to convert vitamin D into its active form. ${ }^{17}$ Isolated peripheral blood mononuclear cells (PBMCs) from patients with SLE incubated with $1,25(\mathrm{OH})_{2} \mathrm{D}$ or its synthetic analogues significantly reduced cellular proliferation, as well as induce polyclonal and anti-dsDNA Ig production. ${ }^{18} 1,25(\mathrm{OH})_{2} \mathrm{D}$ has also been shown to induce apoptosis in activated B cells and to inhibit the generation of plasma cells and postswitch memory B cells, as well as regulatory T cells. ${ }^{1920}$ The importance of vitamin D in innate immunity has been highlighted by studies demonstrating that monocyte/ macrophage responses to bacterial infections via Toll-like receptors (TLRs) are potentially stimulated by 25 -hydroxyvitamin $\mathrm{D}(25(\mathrm{OH}) \mathrm{D})$ following localised induction of both vitamin D receptor (VDR) and $1 \alpha$-hydroxylase. ${ }^{17}$

Interferon $\alpha$ (IFN $\alpha$ ) has been shown to be a key cytokine in the pathogenesis of SLE. Numerous studies have confirmed the association between raised IFN $\alpha$ levels and increased disease activity in SLE. ${ }^{21}$ Strong evidence for the pathogenic role of IFN $\alpha$ in SLE comes from clinical studies showing treatment with recombinant IFN $\alpha$ for malignancies or hepatitis causes de novo SLE, with resolution after discontinuation of treatment. ${ }^{21}$ Induction of IFN $\alpha$ from stimulation of TLRs by nucleic acid-containing immune complexes is thought to be one of the mechanisms by which patients with SLE have increased IFN $\alpha$ activity. ${ }^{21}$ Supporting this hypothesis is evidence that activation of the IFN $\alpha$ pathway is associated with the presence of autoantibodies directed against DNA and RNA binding proteins. ${ }^{2223}$

While in vitro studies have demonstrated a suppressive action of vitamin D on Ig production and the IFN signature, ${ }^{182425}$ an association between vitamin D status in patients with SLE and these disease features has not been previously reported. We examined the prevalence of vitamin D deficiency in antinuclear antibody (ANA)-positive healthy individuals in comparison with ANA-negative healthy individuals and patients with SLE. The relationship 
between vitamin $\mathrm{D}$ status and the interrelated pathways involving B cell activation, autoantibody production and IFN $\alpha$ activity in SLE and healthy individuals was also evaluated.

\section{METHODS}

\section{Study population}

Experiments were performed in accordance with the Helsinki Declaration and approved by the Institutional Review Boards at the Oklahoma Medical Research Foundation and the University of Oklahoma Health Sciences Center. All the study participants provided written informed consent prior to enrolment. All 32 female patients with SLE met at least four of the American College of Rheumatology (ACR) classification criteria. ${ }^{2627}$ Additionally, healthy individuals were recruited to provide control samples and were matched to the patients based on age ( \pm 5 years), race and sex. Only European American women who are Oklahoma residents were included in the study in order to minimise variations in $25(\mathrm{OH}) \mathrm{D}$ levels due to race, sex and latitude.

\section{Data collection}

Demographic information included sex, age and self-reported race. Data were extracted from the medical records of the patients with SLE for ACR classification criteria, age of diagnosis and medication use. Peripheral blood was collected from each participant. Serum samples and plasma were isolated and stored at $-20^{\circ} \mathrm{C}$ until further use. Patients with SLE were evaluated for disease activity by the SELENA-modified SLE disease activity index (SELENA-SLEDAI), physician global assessment (PGA) and systemic lupus activity measure (SLAM). Controls completed the Connective Tissue Disease Screening Questionnaire (CSQ). ${ }^{28}$

\section{5(OH)D levels}

Plasma 25(OH)D levels were determined in duplicate using an enzyme immunoassay kit (Immunodiagnostic Systems, Scottsdale, Arizona, USA) according to the manufacturer's instructions. For this study, vitamin D deficiency was defined as $\leq 20 \mathrm{ng} / \mathrm{ml} .{ }^{29}$ Vitamin D levels were determined from plasma samples obtained on the same date as the blood specimens procured to measure autoantibodies, serum IFN $\alpha$ activity and B cell activation.

\section{Lupus-associated autoantibodies}

ANAs were detected using an Hep-2 indirect immunofluorescent assay (INOVA Diagnostics, San Diego, California, USA) according to the manufacturer's instructions. Anti-double stranded DNA (dsDNA) antibodies were detected using a Crithidia luciliae indirect immunofluorescent assay (INOVA Diagnostics) according to the manufacturer's instructions. Detection of ANA at a dilution of 1:120 or greater and anti-dsDNA at a dilution of 1:30 or greater was considered a positive result. ELISAs were used to evaluate serum for antibodies to Sm, nuclear ribonucleoprotein (nRNP), Ro, La, ribosomal P (ribo P) and cardiolipin, as previously described. ${ }^{30}$ Samples were run in duplicate and normalised to a known positive control.

\section{B cell activity markers}

PBMCs $\left(1 \times 10^{6}\right)$ isolated by Ficoll-Paque gradients of fresh acid-citrate dextroseanticoagulated blood were incubated at $37^{\circ} \mathrm{C}$ for $15 \mathrm{~min}$ and then washed and permeabilised for 10 min with BD Phosflow Perm/Wash Buffer I (BD Biosciences, San Jose, California, USA). After permeabilisation, cells were incubated with anti-CD79a-PE (BD Biosciences) and anti-phospho-Erk (pERK1/2) (Cell Signaling Technology, Danvers, Massachusetts, 
USA). The cells were then washed, stained with FITC goat anti-rabbit IgG (Jackson Immunoresearch, West Grove, Pennsylvania, USA) and analysed using FACS Calibur (BD Biosciences). Representative flow cytometry gating and staining are shown in figure 1 in the online supplement. Median fluorescent intensity values for the levels of pERK1/2 were used on CD79a-gated B cells to rank and normalise the data.

\section{Serum IFNa activity}

The reporter cell assay for serum IFN $\alpha$ activity has previously been described in detail. ${ }^{31}$ Briefly, reporter cells were used to measure the ability of patient serum to upregulate IFNinduced gene expression. The reporter cells (Wistar Institute, Susan Hayflick cells, ATCC No. CCL-25, American Type Culture Collection, Manassas, Virginia, USA) were cultured with $50 \%$ patient serum for $6 \mathrm{~h}$ and then lysed. mRNA was purified from cell lysates and cDNA was made from total cellular mRNA. cDNA was then quantified using real-time PCR. Forward and reverse primers for the genes $M X 1, P K R$ and IFIT, which are known to be highly and specifically induced by IFN $\alpha$, were used in the reaction. ${ }^{32}$ Background gene expression was controlled by amplifying glyceraldehyde 3-phosphate dehydrogenase. IFN $\alpha$ activity values reported represent the number of SD above the mean of healthy donors $(\mathrm{n}=141)$. In this study, IFN $\alpha$ activity values $>1$ are considered high.

\section{Statistical analysis}

Mean 25(OH)D levels were compared using the Kruskal-Wallis test with the Dunn multiple comparisons post-test. Categorical data were analysed using the Fisher exact test.

Continuous variables were analysed using an unpaired $t$ test. Welch's correction was used in instances of unequal variance. Log-transformation was done to normalise serum IFN $\alpha$ activity measures. Pearson correlation was done to assess the relationship between pERK1/2 and $25(\mathrm{OH}) \mathrm{D}$ values. All statistical analyses were carried out with GraphPad Prism Version 5.01 (GraphPad Software, San Diego, California, USA; http://www.graphpad.com).

\section{RESULTS}

\section{Healthy European American ANA-positive individuals and patients with SLE are more likely to have vitamin $D$ deficiency}

25(OH)D levels were measured in 32 European American female patients with SLE and in 32 healthy matched controls. Fourteen of the controls were determined to be ANA-positive. The SLE patient group had a median 25(OH)D level of 17.3 (IQR 11.9-21.2) ng/ml (figure 1A). Interestingly, the 14 controls who were ANA-positive had a median 25(OH)D level of $17.4(14.5-25.8) \mathrm{ng} / \mathrm{ml}$, which was not statistically different from the patients with SLE (Kruskal-Wallis test with Dunn's post-test). In contrast, the 18 controls who were ANAnegative had significantly higher $25(\mathrm{OH}) \mathrm{D}$ levels than the patients with $\mathrm{SLE}(\mathrm{p}<0.01$, figure $1 \mathrm{~A})$. The mean age of the 14 ANA-positive controls was significantly higher than the ANAnegative controls ( 54.1 vs 42.8 years; $\mathrm{p}=0.029$, unpaired $\mathrm{t}$ test). However, in a logistic regression model with vitamin $\mathrm{D}$ status as the outcome and ANA positivity and age as the predictors, age did not predict vitamin $\mathrm{D}$ status $(\mathrm{p}=0.331)$ while ANA positivity remained a significant predictor $(\mathrm{p}=0.025)$. ANA-positive and ANA-negative controls had no significant difference in CSQ scores (median 1.0 (IQR 0.8-2.5) vs 1.0 (IQR 0.0-2.0); p=0.41, MannWhitney test). In addition, there was no difference in body mass index (BMI) values between ANA-positive and ANA-negative controls (26.1 vs $28.4 \mathrm{~kg} / \mathrm{m}^{2} ; \mathrm{p}=0.38$, unpaired t test).

Furthermore, when categorised into vitamin D-deficient $(25(\mathrm{OH}) \mathrm{D}<20 \mathrm{ng} / \mathrm{ml})$ or nondeficient $(25(\mathrm{OH}) \mathrm{D}>20 \mathrm{ng} / \mathrm{ml})$, patients with SLE and ANA-positive controls were more likely to be vitamin D deficient (69\% and 71\%, respectively) than ANA-negative controls 
(22\% deficient) (OR 7.7, 95\% CI 2.0 to $29.4, \mathrm{p}=0.003$ and OR 8.8, 95\% CI 1.8 to 43.6 , $\mathrm{p}=0.011$, respectively, Fisher exact test, figure 1B). Patients with SLE with deficient levels of $25(\mathrm{OH}) \mathrm{D}(\mathrm{n}=22)$ had no statistically significant differences among specific ACR classification criteria, disease activity scores (SLEDAI, SLAM, PGA), BMI or medication use than patients with SLE with non-deficient levels of $25(\mathrm{OH}) \mathrm{D}(\mathrm{n}=10)$. The median (IQR) prednisone dosage for vitamin D-deficient patients was $3(0-5) \mathrm{mg} /$ day compared with $0(0-$ 5) $\mathrm{mg} /$ day for those not deficient in vitamin $\mathrm{D}$ ( $\mathrm{p}=0.507$, Mann-Whitney test). Twenty-three per cent of vitamin D-deficient patients versus $20 \%$ of non-deficient patients were receiving treatment with azathioprine $(\mathrm{p}=1.000), 77 \%$ versus $60 \%$ were taking hydroxychloroquine $(\mathrm{p}=0.407), 23 \%$ versus $10 \%$ were receiving mycophenolate mofetil $(\mathrm{p}=0.637)$ and $23 \%$ versus $10 \%$ were being treated with methotrexate $(\mathrm{p}=0.637)$ (Fisher exact test). In addition, the percentage of vitamin D-deficient patients who were considered to be immunosuppressed (defined as receiving $>10 \mathrm{mg}$ /day prednisone, azathioprine, methorexate or mycophenolate mofetil) was not significantly greater than the percentage of immunosuppressed non-deficient patients ( $64 \%$ vs $40 \%$; $p=0.267$, Fisher exact test). Vitamin D-deficient patients had a higher mean number of ACR classification criteria (6.4 vs 5.3; $\mathrm{p}=0.026$, unpaired $\mathrm{t}$ test).

\section{Increased B cell activation is associated with decreased 25(OH)D in SLE}

An increase in B cell activation as measured by pERK1/2 was correlated with decreased levels of $25(\mathrm{OH}) \mathrm{D}$ in patients with SLE $(\mathrm{r}=-0.40, \mathrm{p}=0.03$; figure $2 \mathrm{~A})$. No correlation was seen between $B$ cell activity and 25(OH)D levels in controls ( $p E R K 1 / 2: r=-0.05, p=0.79$ ). Additionally, patients with $25(\mathrm{OH})$ D levels $<20 \mathrm{ng} / \mathrm{ml}$ had increased mean (SD) pERK1/2 compared with patients with 25(OH)D levels $>20 \mathrm{ng} / \mathrm{ml}$ (figure $2 \mathrm{~B} ; 56.4(24.2)$ vs 39.6 (33.2); $\mathrm{p}=0.045$, unpaired t test with Welch's correction of log-transformed data).

Interestingly, there was also a trend for vitamin $\mathrm{D}$-deficient patients to be anti-Ro positive compared with non-deficient patients (59\% vs 20\%) (OR 5.8, 95\% CI 0.99 to 33.8; $\mathrm{p}=0.061$, Fisher exact test). Anti-Ro-positive patients in this small cohort were not more likely to have documented photosensitivity than anti-Ro-negative patients ( $60 \%$ vs $77 \%$; $p=0.450$, Fisher exact test). This trend was not seen with any other measured lupus-associated antibody (dsDNA, La, Sm, nRNP, ribo P, aPL).

\section{Vitamin D-deficient patients with SLE have increased IFNa activity}

Serum IFN $\alpha$ activity was measured in serum samples from patients with SLE and compared between patients with $25(\mathrm{OH})$ D levels $>20 \mathrm{ng} / \mathrm{ml}(\mathrm{n}=10)$ and $<20 \mathrm{ng} / \mathrm{ml}(\mathrm{n}=22)$. Vitamin Ddeficient patients had increased IFN $\alpha$ activity compared with patients with $25(\mathrm{OH}) \mathrm{D}>20$ $\mathrm{ng} / \mathrm{ml}$ ( $\mathrm{p}=0.02$, unpaired $\mathrm{t}$ test with Welch's correction of log-transformed data; figure $3 \mathrm{~A}$ ). Vitamin D-deficient patients had a mean (SD) serum IFN $\alpha$ activity of 3.5 (6.6) compared with 0.34 (0.33) in non-vitamin D-deficient patients. Anti-Ro, anti-dsDNA and anti-nRNP have each been shown to be independently associated with high serum IFN $\alpha$ activity and, in addition, have been shown to influence serum IFN $\alpha$ activity additively. ${ }^{3233}$ We therefore analysed the number of lupus-associated autoantibody specificities present in patients with high and low IFN $\alpha$ activity. Patients with SLE who had high IFN $\alpha$ activity (>1 SD above the mean of healthy controls) had an increased number of lupus-associated autoantibody specificities compared with those who had low IFN $\alpha$ activity ( $<1$ SD above the mean of healthy controls) ( 2.6 vs $0.9 ; \mathrm{p}=0.002$, unpaired t test; figure $3 \mathrm{~B}$ ). To determine whether the relationship between $25(\mathrm{OH}) \mathrm{D}$ and IFN $\alpha$ activity was dependent on the number of autoantibody specificities, various statistical models were compared using logistic regression. In these models the outcome variable was IFN $\alpha$ activity, with high levels defined as IFN $\alpha$ activity $>1$ SD above the mean of healthy controls and low levels defined as IFN $\alpha$ activity $<1$ SD below the mean. The number of lupus-associated autoantibody specificities and $25(\mathrm{OH}) \mathrm{D}$ values are the predictor variables. In single-predictor logistic regression 
models, both $25(\mathrm{OH}) \mathrm{D}(\mathrm{p}=0.033)$ and number of autoantibody specificities $(\mathrm{p}=0.023)$ are significantly associated with IFN $\alpha$ activity. The best fitting single-predictor model was compared with a model with both $25(\mathrm{OH}) \mathrm{D}$ and number of autoantibody specificities as predictors using the likelihood ratio test, and the fit was significantly improved with the twopredictor model $\left(\chi^{2}=3.931, \mathrm{p}=0.047\right)$. This suggests that, although the number of autoantibody specificities and $25(\mathrm{OH}) \mathrm{D}$ levels are correlated $\left(\mathrm{r}^{2}=0.138, \mathrm{p}=0.037\right)$, both are good independent predictors of IFN $\alpha$ activity.

\section{DISCUSSION}

Although increasing evidence supports the role of vitamin D in modulating the immune system, many details remain to be elucidated. While specific mechanisms have been discovered for the influence of vitamin D on innate immunity, the potential role for vitamin $\mathrm{D}$ in the adaptive immune system is still not clear. Several mechanisms exist by which vitamin $\mathrm{D}$ could potentially modulate adaptive immune responses, including modulation of antigen presentation as well as direct actions on $\mathrm{T}$ and $\mathrm{B}$ lymphocytes.

This study suggests a role for vitamin D in modulating auto-antigenic immune responses. Vitamin D deficiency was associated with an increased presence of autoantibodies in healthy controls. While vitamin D deficiency has been reported in many autoimmune diseases, this is the first observation in ANA-positive healthy individuals. This finding is interesting because patients with autoimmune disease, especially those with SLE, possess many risk factors for vitamin D deficiency whereas healthy controls do not. This provides epidemiological evidence to suggest that vitamin D deficiency in autoimmunity is not solely a consequence of lifestyle changes associated with the disease. A longitudinal study would determine if replenishing vitamin $\mathrm{D}$ to sufficient levels would cause a decrease in ANA titres.

We also showed evidence of a relationship between vitamin D levels in patients with SLE and the magnitude of B lymphocyte activation in PBMCs, as determined by pERK1/2 levels. This observation suggests that vitamin D deficiency could be playing a role in the B cell hyperactivity seen in patients with SLE, thus contributing to an increased production of autoantibodies. Interestingly, this same correlation was not seen in the controls, suggesting a potential gene-environment interaction between SLE susceptibility genes and vitamin D. In this manner, vitamin D deficiency would contribute to B cell hyperactivation and autoantibody production in genetically susceptible individuals. Vitamin D deficiency is probably not sufficient to cause B cell hyperactivation and autoantibody production, but rather is a contributing factor along with other genetic and environmental risks.

The hypothesis that vitamin D deficiency contributes to increased B cell activation in patients with SLE and increased production of autoantibodies, in particular those directed against nucleic acids, provides a mechanism for the association of vitamin D deficiency with increased IFN $\alpha$ activity (working hypothesis shown in figure 4). Nucleic acids contained within autoantibody immune complexes can activate TLRs, thus promoting IFN $\alpha$ production from plasmacytoid dendritic cells (pDCs) in patients with SLE. ${ }^{34}$ Vitamin D may bind vitamin $\mathrm{D}$ receptors present in $\mathrm{pDCs}$ and influence their IFN $\alpha$ production, although it has been shown that $1,25(\mathrm{OH})_{2} \mathrm{D}$ did not modulate IFN $\alpha$ production by $\mathrm{pDCs}$ in vitro at the concentrations used. ${ }^{35}$ Additionally, it has been shown that vitamin D suppresses the expression of the IFN signature in myeloid-derived dendritic cells (MDDCs). This was accomplished using MDDCs from patients with SLE as well as MDDCs generated from controls which had been incubated with plasma from patients with SLE. ${ }^{2425}$ 
Experimental studies have also shown that $1,25(\mathrm{OH})_{2} \mathrm{D}$ is able to skew the $\mathrm{T}$ cell compartment into a more anti-inflammatory and regulated state, with inhibitory actions on Th1 and Th17 cells and promoting the development of CD4 CD25 Foxp $3^{+}$regulatory T cells (Treg). ${ }^{17}$ Vitamin D has been shown to induce tolerogenic dendritic cells, which promote Treg cell development and enhance recruitment of Treg cells to inflammatory sites. ${ }^{17}$ Thus, there are several different possible pathways by which vitamin D can influence the pathogenesis of SLE, B cell activity and autoantibody production.

The fact that both ANA-positive healthy individuals and patients with SLE have decreased vitamin D suggests that the mechanism operates early in the steps to SLE development, before the appearance of clinical findings. Beyond considering the molecular mechanisms by which vitamin $\mathrm{D}$ deficiency would predispose to autoimmunity, the extraordinarily high prevalence of vitamin D deficiency in ANA-positive healthy individuals and patients with SLE strongly suggests that repletion with vitamin D should be considered. A recent study sought to examine the effects of oral vitamin D supplementation on disease activity in SLE; however, more than $70 \%$ of the patients in the study still had insufficient levels of vitamin D after 2 years of treatment. ${ }^{36}$ While this study did not report any improvements in SLE disease activity after oral administration of vitamin $\mathrm{D}$, interpretation of the results is limited by the small percentage of patients with SLE who achieved adequate $25(\mathrm{OH}) \mathrm{D}$ levels. Although no definitive study has been published demonstrating a beneficial effect of vitamin D supplementation on SLE disease severity, current knowledge supports vitamin D replacement for calcium homeostasis, bone health and potential immune system benefits.

\section{Acknowledgments}

The authors would like to thank all the study participants for their time and commitment to the study as well as the referring physicians: Drs C Carson, A A Kumar, L Zacharias and physician assistants T Aberle and J K Shoemaker. The authors would also like to thank J Anderson, W Klein, G Vidal and J Levin for their technical assistance, as well as S Stewart for his assistance with the statistical analysis.

Funding This work was supported by the National Institutes of Health (NIAID: HHSN266200500026C, AR058554, RR015577, AI082714, AI24717, AR24260, AI083194, AR052364 and AR053483), Kirkland Foundation Scholar Support, OMRF J Donald Capra Fellowship Support, US Department of Veteran Affairs and the OMRF Lou C Kerr Chair in Biomedical Research.

\section{References}

1. Adorini L, Penna G. Control of autoimmune diseases by the vitamin D endocrine system. Nat Clin Pract Rheumatol. 2008; 4:404-12. [PubMed: 18594491]

2. Kamen DL, Cooper GS, Bouali H, et al. Vitamin D deficiency in systemic lupus erythematosus. Autoimmun Rev. 2006; 5:114-17. [PubMed: 16431339]

3. Toloza SM, Cole DE, Gladman DD, et al. Vitamin D insufficiency in a large female SLE cohort. Lupus. 2010; 19:13-19. [PubMed: 19897520]

4. Ruiz-Irastorza G, Egurbide MV, Olivares N, et al. Vitamin D deficiency in systemic lupus erythematosus: prevalence, predictors and clinical consequences. Rheumatology (Oxford). 2008; 47:920-3. [PubMed: 18411213]

5. Wright TB, Shults J, Leonard MB, et al. Hypovitaminosis D is associated with greater body mass index and disease activity in pediatric systemic lupus erythematosus. J Pediatr. 2009; 155:260-5. [PubMed: 19446841]

6. Orbach H, Zandman-Goddard G, Amital H, et al. Novel biomarkers in autoimmune diseases: prolactin, ferritin, vitamin D, and TPA levels in autoimmune diseases. Ann N Y Acad Sci. 2007; 1109:385-400. [PubMed: 17785327]

7. Vacca A, Cormier C, Piras M, et al. Vitamin D deficiency and insufficiency in two independent cohorts of patients with systemic sclerosis. J Rheumatol. 2009; 36:1924-9. [PubMed: 19648299] 
8. Hajas A, Sandor J, Csathy L, et al. Vitamin D insufficiency in a large MCTD population. Autoimmun Rev. 2011; 10:317-24. [PubMed: 21156217]

9. Pelajo CF, Lopez-Benitez JM, Miller LC. Vitamin D and autoimmune rheumatologic disorders. Autoimmun Rev. 2010; 9:507-10. [PubMed: 20146942]

10. Zold E, Szodoray P, Gaal J, et al. Vitamin D deficiency in undifferentiated connective tissue disease. Arthritis Res Ther. 2008; 10:R123. [PubMed: 18928561]

11. Nagpal S, Na S, Rathnachalam R. Noncalcemic actions of vitamin D receptor ligands. Endocr Rev. 2005; 26:662-87. [PubMed: 15798098]

12. Moser KL, Kelly JA, Lessard CJ, et al. Recent insights into the genetic basis of systemic lupus erythematosus. Genes Immun. 2009; 10:373-9. [PubMed: 19440199]

13. Cooper GS, Dooley MA, Treadwell EL, et al. Hormonal, environmental, and infectious risk factors for developing systemic lupus erythematosus. Arthritis Rheum. 1998; 41:1714-24. [PubMed: 9778212]

14. Amital H, Szekanecz Z, Szücs G, et al. Serum concentrations of $25-\mathrm{OH}$ vitamin D in patients with systemic lupus erythematosus (SLE) are inversely related to disease activity: is it time to routinely supplement patients with SLE with vitamin D? Ann Rheum Dis. 2010; 69:1155-7. [PubMed: 20439290]

15. Cutolo M, Otsa K. Review: vitamin D, immunity and lupus. Lupus. 2008; 17:6-10. [PubMed: 18089676]

16. Cutolo M, Otsa K, Paolino S, et al. Vitamin D involvement in rheumatoid arthritis and systemic lupus erythematosus. Ann Rheum Dis. 2009; 68:446-7. [PubMed: 19213751]

17. Kamen DL, Tangpricha V. Vitamin D and molecular actions on the immune system: modulation of innate and autoimmunity. J Mol Med. 2010; 88:441-50. [PubMed: 20119827]

18. Linker-Israeli M, Elstner E, Klinenberg JR, et al. Vitamin D(3) and its synthetic analogs inhibit the spontaneous in vitro immunoglobulin production by SLE-derived PBMC. Clin Immunol. 2001; 99:82-93. [PubMed: 11286544]

19. Chen S, Sims GP, Chen XX, et al. Modulatory effects of 1,25-dihydroxyvitamin D3 on human B cell differentiation. J Immunol. 2007; 179:1634-47. [PubMed: 17641030]

20. Toubi E, Shoenfeld Y. The role of vitamin D in regulating immune responses. Isr Med Assoc J. 2010; 12:174-5. [PubMed: 20684184]

21. Crow MK, Kirou KA. Interferon-alpha in systemic lupus erythematosus. Curr Opin Rheumatol. 2004; 16:541-7. [PubMed: 15314491]

22. Kirou KA, Lee C, George S, et al. Activation of the interferon-alpha pathway identifies a subgroup of systemic lupus erythematosus patients with distinct serologic features and active disease. Arthritis Rheum. 2005; 52:1491-503. [PubMed: 15880830]

23. Niewold TB, Kelly JA, Flesch MH, et al. Association of the IRF5 risk haplotype with high serum interferon-alpha activity in systemic lupus erythematosus patients. Arthritis Rheum. 2008; 58:2481-7. [PubMed: 18668568]

24. Kamen D, Aranow C. Vitamin D in systemic lupus erythematosus. Curr Opin Rheumatol. 2008; 20:532-7. [PubMed: 18698173]

25. Ben-Zvi I, Aranow C, Mackay M, et al. The impact of vitamin D on dendritic cell function in patients with systemic lupus erythematosus. PLoS ONE. 2010; 5:e9193. [PubMed: 20169063]

26. Tan EM, Cohen AS, Fries JF, et al. The 1982 revised criteria for the classification of systemic lupus erythematosus. Arthritis Rheum. 1982; 25:1271-7. [PubMed: 7138600]

27. Hochberg MC. Updating the American College of Rheumatology revised criteria for the classification of systemic lupus erythematosus. Arthritis Rheum. 1997; 40:1725. [PubMed: 9324032]

28. Karlson EW, Sanchez-Guerrero J, Wright EA, et al. A connective tissue disease screening questionnaire for population studies. Ann Epidemiol. 1995; 5:297-302. [PubMed: 8520712]

29. Holick MF. Vitamin D deficiency. N Engl J Med. 2007; 357:266-81. [PubMed: 17634462]

30. Heinlen LD, McClain MT, Ritterhouse LL, et al. $60 \mathrm{kD}$ Ro and nRNP A frequently initiate human lupus autoimmunity. PLoS ONE. 2010; 5:e9599. [PubMed: 20224770] 
31. Hua J, Kirou K, Lee C, et al. Functional assay of type I interferon in systemic lupus erythematosus plasma and association with anti-RNA binding protein autoantibodies. Arthritis Rheum. 2006; 54:1906-16. [PubMed: 16736505]

32. Niewold TB, Hua J, Lehman TJ, et al. High serum IFN-alpha activity is a heritable risk factor for systemic lupus erythematosus. Genes Immun. 2007; 8:492-502. [PubMed: 17581626]

33. Weckerle CE, Franek BS, Kelly JA, et al. Network analysis of associations between serum interferon- $\alpha$ activity, autoantibodies, and clinical features in systemic lupus erythematosus. Arthritis Rheum. 2011; 63:1044-53. [PubMed: 21162028]

34. Lövgren T, Eloranta ML, Båve U, et al. Induction of interferon-alpha production in plasmacytoid dendritic cells by immune complexes containing nucleic acid released by necrotic or late apoptotic cells and lupus IgG. Arthritis Rheum. 2004; 50:1861-72. [PubMed: 15188363]

35. Penna G, Amuchastegui S, Giarratana N, et al. 1,25-Dihydroxyvitamin D3 selectively modulates tolerogenic properties in myeloid but not plasmacytoid dendritic cells. J Immunol. 2007; 178:14553. [PubMed: 17182549]

36. Ruiz-Irastorza G, Gordo S, Olivares N, et al. Changes in vitamin D levels in patients with systemic lupus erythematosus: effects on fatigue, disease activity, and damage. Arthritis Care Res (Hoboken). 2010; 62:1160-5. [PubMed: 20235208] 


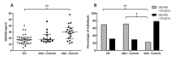

Figure 1.

Antinuclear antibody (ANA)-positive healthy individuals and patients with systemic lupus erythematosus (SLE) are more likely to be deficient in vitamin D. (A) Median (IQR) 25hydroxyvitamin D levels were 17.3 (11.9-21.2) $\mathrm{ng} / \mathrm{ml}$ in patients with SLE ( $\mathrm{n}=32), 17.4$ (14.5-25.8) $\mathrm{ng} / \mathrm{ml}$ in ANA-positive controls $(\mathrm{n}=14)$ and $29.4(19.0-36.3) \mathrm{ng} / \mathrm{ml}$ in ANAnegative controls $(n=18)$. Bars indicate IQR. **p<0.01, Kruskal-Wallis test with Dunn's multiple comparison. (B) Patients with SLE and ANA-positive controls were more likely to be vitamin D deficient (69\% and 71\%, respectively) than ANA-negative controls (22\%). $* * \mathrm{p}=0.003, * \mathrm{p}=0.011$ (Fisher exact test). 


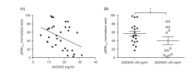

Figure 2.

Lower 25-hydroxyvitamin D (25(OH)D) levels are associated with increased B cell activation in patients with systemic lupus erythematosus (SLE). (A) Increased B cell activation (as measured by phospho-ERK (pERK1/2)) was correlated with decreased $25(\mathrm{OH}) \mathrm{D}$ levels in patients with SLE $(\mathrm{r}=-0.40, \mathrm{p}=0.03)$. (B) Patients with SLE with $25(\mathrm{OH}) \mathrm{D}$ levels $<20 \mathrm{ng} / \mathrm{ml}$ had higher $\mathrm{B}$ cell activation (as measured by pERK1/2) than patients with $25(\mathrm{OH}) \mathrm{D}$ levels $>20 \mathrm{ng} / \mathrm{ml} ;{ }^{*} \mathrm{p}=0.045$ (unpaired t test with Welch's correction of log-transformed data). Error bars indicate SEM. 

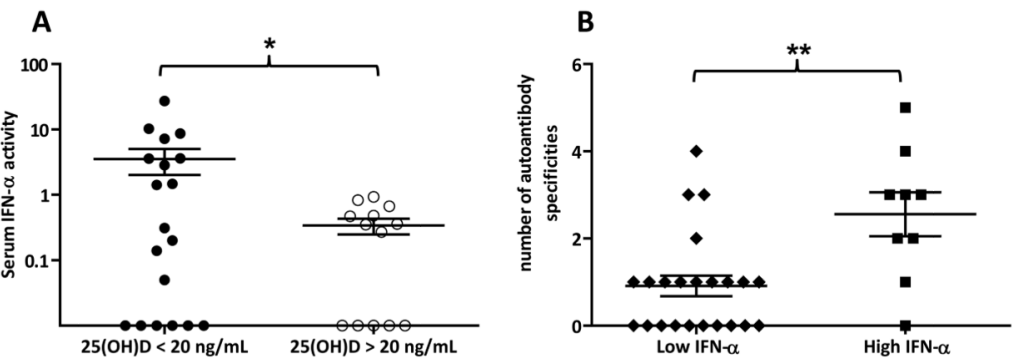

Figure 3.

Increased serum interferon $\alpha$ (IFN $\alpha)$ activity is associated with vitamin D deficiency and increased number of autoantibody specificities. (A) Patients with systemic lupus erythematosus (SLE) with 25-hydroxyvitamin D $(25(\mathrm{OH}) \mathrm{D})<20 \mathrm{ng} / \mathrm{ml}$ had mean (SD) serum IFN $\alpha$ activity of 3.53 (6.56) compared with $0.34(0.33)$ in patients with $25(\mathrm{OH}) \mathrm{D}>20$ $\mathrm{ng} / \mathrm{ml}$. * $\mathrm{p}=0.02$ (unpaired t test with Welch's correction of log-transformed data). (B) Patients with SLE with low IFN $\alpha$ activity (IFN $\alpha$ activity <1 SD above the mean of healthy controls) had fewer mean number of autoantibody specificities than patients with high IFN $\alpha$ activity (IFN $\alpha$ activity $>1 \mathrm{SD}$ above the mean of healthy controls): 0.9 vs 2.1 . $* * \mathrm{p}=0.002$ (unpaired t test). Errors bars indicate SEM. 


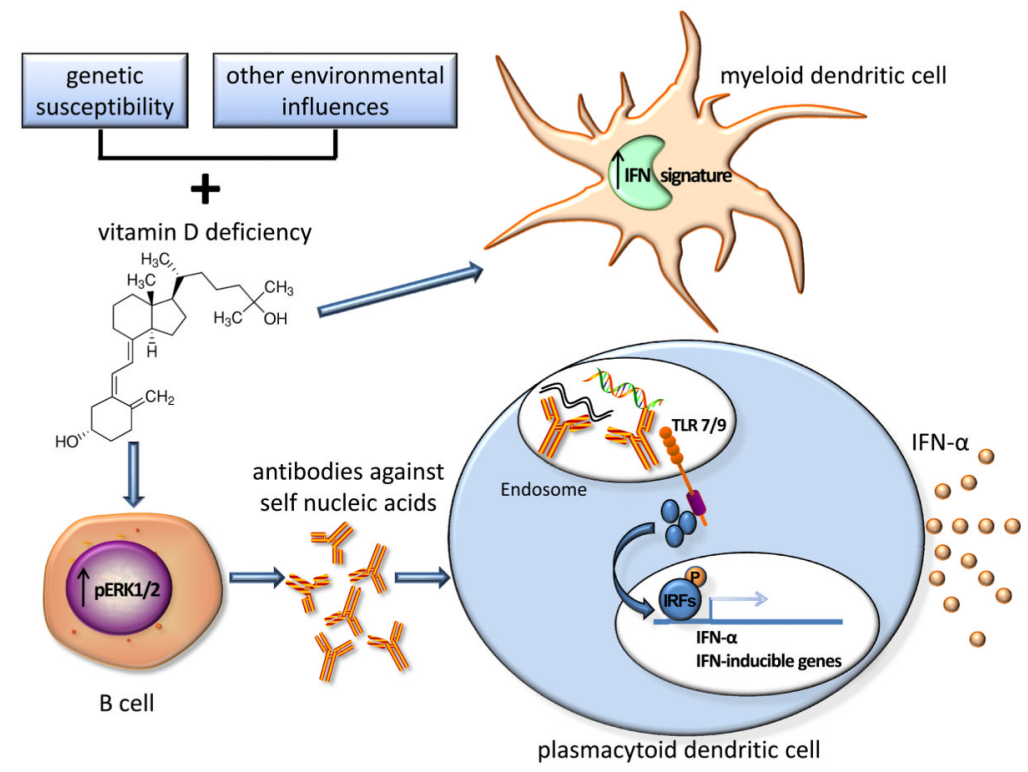

Figure 4.

Potential mechanism for the role of vitamin D in B cell hyperactivity, autoantibody production and interferon $\alpha$ (IFN $\alpha$ ) activity. Together with genetic susceptibility and other environmental factors, vitamin D deficiency could contribute to increased B cell activation and autoantibody production. This increase in autoantibody production, specifically of antibodies directed against self-nucleic acids, could lead to an increase in IFN $\alpha$ production by plasmacytoid dendritic cells via Toll-like receptor (TLR) signalling mediated by immune complexes. Vitamin D deficiency could also contribute to an increased IFN signature in myeloid dendritic cells. 